\title{
The premises and goals of studies on the perception of culturally-formed landscape
}

\author{
Dorota Angutek \\ (University of Zielona Gora; The Institute of Sociology)
}

In this article, I outline and discuss that aspect of participation in cultural landscape which pertains to perception, both as experienced and as designed by members of a given community. I assume that each community (local, regional, or even small, primary communities such as family, neighbourhood, circle of friends or colleagues) has its own pattern of participation in the surrounding natural landscape. In many cases the pattern is repeated, but its configuration can be quite specific, expressing itself in varying intensity of qualities, arrangements of perceptual components, as well as the values attached to them by the subjects of culture.

I believe that the approach to the perception of landscape construed as a synthetic act of cognition and recording sensory data, projection of inner mental reality onto external nature, combined with reception of new sensorial input from the outside is one of the fundamental problems which have to be addressed in interdisciplinary studies of landscape. The many years of research on the subjective reception of landscape in which I have been involved offer grounds for a recapitulation, and grounds for suggesting further objectives to be accomplished in the field.

A landscape is an entity which has been undergoing not only social and spatial but also historical transformation, so there is no single definition of landscape: there are as many landscapes as have been formulated by various cultures and societies. It suffices to review our basic knowledge about the tremendously extensive and extremely diverse understanding and perception of landscape in European culture in the course of particular cultural-historical periods, including visual arts and literature, to make justify this assertion with respect to scientific research (Angutek 2013a, 61-81). Naturally, this is not a new thesis, being the principal theme in Phil Macnaghten's and John Urry's Contested Natures (1998). However, the British sociologists examine that diversity in a synchronic perspective, as an accrued historical legacy, whose ideas functioned in the $20^{\text {th }}$ century as a proposal for those who became involved in environmentalism and ecology. 
Thus collated "landscapes" - both as an alternative proposal in the current cultural offer and from a diachronic perspective-are made up of elements that intermingle. Indeed, they tend to be spontaneously selected, compiled or contaminated by the subjects of our late modern culture. ${ }^{1}$

As for culture, I understand it as configured patterns of thought and action which effectively amount to a system that remains functionally co-dependent with environmental, historical, normative and social determinants. Apart from adaptation to the external conditions of the environment, culture is simultaneously a symbolic system, expressed through motives and values which members of a given society deem emblematic of themselves and which have been acquired in a particular cultural tradition-not thanks to genes and memes. This claim is crucial for an understanding of the research perspective in anthropology and cultural studies. Still, my position in not entirely ideational because I find that cultural patterns are anchored both in shared memory and historically transmitted socialcultural knowledge, as well as organically entrenched in the brain and body of a person brought up in a given culture in the course of their individual life in the group they belong to.

The "subjective approach" which I employ means the scientific study of landscape from the standpoint of the viewer, user and participant in the landscape, or more precisely in the vision established and consolidated in a given society or social-cultural group at a specific historical period. In short, I address landscape from the position of the engaged attitude of an individual as a subject of culture-to borrow Hannah Arendt's phrase (Arendt 2010, 27, 41). On the other hand, Arendt distinguished the distanced observer attitude, which is assumed by a researcher striving to arrive at objective findings of inquiry into participation in culture or, in our, case, participation in landscape. This approach fits within a broader perspective of the theory of individual participation in culture. The subjective perception and valuation of landscape means that its paradigm is shared by members of a given social and/or cultural group at a specific time and place. In other words, we always perceive nature via a cultural humanistic factor, characteristic for a given community (in accordance with Jerzy Kmita's "socialized" variant of the construct (Kmita 1985, 40-44)). Florian Znaniecki coined the original phrase to express idiosyncratic differences between individuals, though he also admitted the possibility that it constitutes a cultural "filter" in the perception of reality (Znaniecki 1988, 24-26). Furthermore, Anna Pałubicka introduces an analogous construct defined as the perception factor, which distinguishes people originating from different cultures (Pałubicka 2013, 89). One could advance a thesis, not a new one, that representatives of various social groups or categories are impacted by distinct perceptual factors with respect to landscape, and thus they create the

1 I distinguish between both notions as involving, respectively, creative and non-creative synthesis; see Angutek 2013. 
corresponding panorama depending on social and demographic variables (such as age, gender, education, location of upbringing and origin, profession) as well as on the kind of socialization and inculturation to which they have been exposed (Angutek 2013 and 2013a, 218-240).

Our problem clearly lies at the foundation of human constitution as a dualistic being: one who thinks symbolically (using images and abstract figures) and yet communicates with the world via corporeal sensory faculties. Perception is already a combination, the result of both of these aspects of human functioning. It is culturally moulded in a long process of learning the concepts and connecting them with the physical world experienced by the senses. Hence perception is always suspended between concepts and experienced input of the senses. Without going further than philosophical writings concerned with perception (or more general issues where perception plays the key role), or studies on cognitive systems encountered in cultures, an area explored by cultural anthropology, it becomes evident that the issue is not only a fundamental one for science, but also an incredibly difficult one to describe and explain. On the other hand, it is not the complexity of the elements which resists inquiry (since we are responsible for the tremendous body of data generated due to the analytical approach), but the synthetic nature of perception-it does not yield to analysis in an exhaustive manner. After all, synthesis is not the reverse of analysis as has been assumed, and it is certainly no basic state of a given phenomenon or process. This kind of simplification may apply to laboratory research and, more generally, investigations in the field of natural sciences, though at a fairly rudimentary level; for instance, contemporary physics has been taking advantage of synthetic constructs reflecting a state which cannot be broken down into components, such as a string or a gravitational theory. (Hence the linguistic dispute in which rival disputants side either with Willard Van Orman Quine's empiricism and his concept of analytic and synthetic statements, or opt for Ludwig Wittgenstein's pragmatism and performativity conception of language. With regard to perception as a synthetic process, Wittgensteinian concepts correspond better with the realities of the synthetic functioning of the human mind in perception.)

What, then, is landscape if the above descriptive-explanatory paradigm is applied?2 Considering the difficulties outlined so far, as well as the barriers resulting from the methodology of studies into subjectively experienced cultural and physical reality, the answer is neither straightforward nor unequivocal. I construe landscape as a mental, culturally propagated entity, which emerges from a conjunction of

2 I avoid the term "theory" deliberately, bearing in mind its having been discredited in the wake of post-modern critique in social sciences. Currently, one rather speaks of interpretation, both in terms of description and explanation. I understand scientific interpretation in the methodological sense, i.e. from the position of cognitive relativism, whereby it is doubtful that a researcher can transcend the horizon of their own culture so as to arrive at knowledge which has not been mediated by any culture, i.e. at objective cognition. We may only strive for "objectivizing" inquiry but an objective one remains unattainable. 
various factors: sensory perception and earlier or simultaneous concepts of Nature which are projected on that perception. The notion of Nature with a capital " $\mathrm{N}$ " is distinct from "nature" denoting the natural world-here I draw on Maria Janion (1994, 14ff.). The former pertains to the idea of nature, i.e. culturally and historically transformed notions about it, its axiological, aesthetic and utilitarian evaluations, the perception factor etc.; the latter, on the other hand, applies to reality apprehended physically by natural scientists. Their standpoint presumes that it is perceived and studied objectively, an unattainable standpoint in my view. Even precise measurements and mathematical data are products of culture, as opposed to non-mediated states of material reality. The feasibility of an objective knowledge of nature had already been questioned by Znaniecki in the 1920s (Znaniecki 1988, 31-56).

In short, therefore, landscape is a mental creation and as such constitutes an image and an associated experience including sensory experience, re-established when imagined. In contact with nature it undergoes various transformations induced by new sensory information and its integration with the existing mental model. In the act of perception ideas of the mind and sensory stimuli become superimposed, engendering a landscape in motion with its endless transformations. Only historical recollections of old exemplars of landscape offer finite, determined and immobile landscapes, arrested by the shutter of the eye of a painter, poet, or graphic artist. These may be examined both analytically and synthetically, but the landscape of a living culture we are members of is invariably set in motion by thoughts and sensations transmitted into our minds. Thus landscape is the crop of perception, a synthetic and dynamic entity modified by what it is fed by the five senses individually as well as together (manifested in synergic processes and culturally developed syntheses of acts of synaesthesia (Angutek 2013, 2013a). Landscape is within the mind and at the same time it is experienced in sensations which have previously been shaped by culture during the period of socialization and enculturation, processes going on throughout one's life. By immersion in culture, whose content changes as time goes by, the individual may modify, amend and enrich their vision of Nature and its perception.

The manner in which these two, mental and sensory dimensions are synthesized can most likely be ascertained by cognitivists, neurobiologists-though only those who represent the bias of the humanities: neurophenomenologists, ecologists of the mind, and enactivists. Therefore I believe that only joint transdisciplinary studies, not excluding natural scientists, may resolve the issue whose lineage spans several centuries.

I will now attempt a brief description and distinguish two mental states referred to as consciousness with its self-awareness on the one hand, and the self with its selfknowledge, all of which take part in the acts of perception. In doing so, I will try to seek a transdisciplinary solution to the problem outlined above while drawing on 
cultural studies, cultural anthropology and enactivism. Consciousness is always a consciousness of something. In contrast, the self is a not necessarily conscious, yet it can be reached through self-knowledge. It is very seldom consciously reflected on, as no corresponding conceptual idiom exists; it is rather accessible via extraverbal communication.

Each mental state called "consciousness" is filled with content with respect to which people express particular attitudes or opinions, and by which they are motivated to action. The fact that the 'average person' is not aware of the properties of culture as a system governed by rules beyond the knowledge of individuals does not mean that its subjects remain unaware of culture. One is dealing with the dichotomy of "explicit/implicit culture" where only the researcher is aware of the latter (Burszta 1987). By attempting to reconcile enactivist knowledge with knowledge of cultural anthropology and cultural studies, I try to determine the kinds of relationships arising between both concepts, so as to arrive at more detailed data concerning perception. Interdisciplinary findings are collocated by the general cognitive perspective of cultural anthropology which presupposes that society and its culture are the catalyst and carrier of human thought. Moreover, I adopt the connectionist and enactivist concept of links between human culture in its ideational dimension and its surroundings. ${ }^{3}$

Consciousness has cultural foundations whereas the self is grounded in biological foundations, but their separation is not written in stone. The self is also partly colonized and modified by culture, while consciousness is to a lesser degree influenced by functions of the self. I assume therefore that the vectors of development of consciousness as an aspect of the mind, and brain as a fundament of the self at the molecular level issue from the sphere of culture and only to a minor extent from the biologically formed brain. Although I do not dispute the organic substratum of culture, which I take to amount to the colonization of brain by culture at a somatic, microcellular level, I question the neurobiological thesis assuming a biological origin of human culture based on biologically inherited properties of the brain (LeDoux 1996; Damasio 1999, 2010). This leads to my principal assertion that all thought processes are supported by (but do not originate from) organic structures. I acknowledge the existence of somatic links between the body and culture whose carrier is the mind. Capturing the ways in which both spheresthe biological and the cultural-determine those processes is extremely difficult to achieve at a microcellular level. Nevertheless, I believe that culture penetrates deep into the soma, going against classical cultural anthropology and its related social disciplines, with the exception of Bateson and Levi-Strauss. I would therefore argue that cultural processes should be extended to accommodate the organic,

3 See e.g. Bateson 1972; Varela, Rosch, and Thompson 1991. 
cellular sphere, whereby the human being may be approached as an entity living in the biological and mental sense.

The empirically and logically unfounded thesis advanced by neurobiologiststhat extended consciousness learns from proto-consciousness-is a problematic one. Neurobiologists have failed to account for the saltatory differences between functions and quality of response in older and younger cortex. According to them, the latter are stimulated by self-development, but these researchers do not take into account that self-development is provoked, even enforced by social interaction, as one of the functions of culture which is strictly linked to communication. Finally, it is culture which causes potential sensory predispositions to be in part emphasized or marginalized socially.

Neurobiologists claim that our inability to control emotions and the fact that they often induce advanced confusion attest to the extra-conscious nature of emotions. Proto-consciousness, they argue, is non-volitional and the emotions it triggers are spontaneous reactions over which we have no control. I do agree that the self-conditioned as it is by the reactions of the limbic system and the old cortexis filled with congenital emotional potential, but the mode in which this content is subsequently expressed is shaped by culture. As an example, one could quote grief following the loss of a loved one (which is also observed in many animal species), whose manifestations are different among e.g. effusive Arabs and the reserved Balinese or Tibetans. So, the thesis advanced by neurobiologists can be accepted only conditionally, for certain societies. Evidence supporting the proposition that culture provokes and moulds the working of the mind is found in all kinds of studies whose results indicate that there are disparities in brain activity between representatives of different generations who have been schooled according to distinct educational paradigms (Carr 2010); the same applies to entire societies and social groups.

The general contentions presented here rely on the theoretical and practical research achievements of the interdisciplinary subfields of cultural anthropology. These include proxemics, kinesics, connectionism and emergentism, in which the transition between the self and consciousness, biology and thinking is construed as a staggered change in development (which does not necessarily constitute progressive evolution). Studies initiated by the research team of the hospital in Palo Alto, then anthropologists of the senses-including the Canadian variant (Angutek 2010), and subsequently the anthropology of experience, in whose domain the issues of performativity and synergy have been addressed by e.g. Victor Turner and his collaborators (Turner 1986). Those subdisciplines of anthropology developed under the influence of ethology and Merleau-Ponty's phenomenology of perception. Among the anthropologists who may be associated with the phenomenology of the French philosopher as well as-let it be noted-Heidegger's existential hermeneutics, one should mention the English social anthropologist Tim Ingold, who 
independently and creatively compiles the aforesaid philosophies, as well as taking advantage of the studies which began with Gregory Bateson and Heidegger. In contrast, neurobiologists integrated the achievements of their discipline with those of cognitive sciences and phenomenology as part of a subdiscipline called "enactivism". The latest outcome of that alliance is the increasingly popular neurophenomenology (also referred to as "experimental phenomenology") (Przegalińska 2013). This diversification is further compounded by concepts deriving from the idea of James Gibson's “embodied mind" (Gibson 1979), e.g. embodied functionalism conceived by Andy Clark (1989). The knowledge that the above subdisciplines yield, if accepted, is subordinated by cultural anthropologists, as well as practitioners of cultural studies and sociologists of culture to the priorities of broadly understood historical-cultural determinism.

In conclusion, the anatomy of the brain is not decisive for the perceptual, symbolic and emotive capabilities of the human being. I believe that the brains of people native to distinct cultures differ at the molecular and functional level, while the utilization of their inherent predispositions is dependent on the requirements, values and processes of a given culture.

The initiative of transdisciplinary studies should be undertaken by cultural studies, a discipline which by definition integrates the achievement of various disciplines of social sciences and humanities. After all, one sees that projects embarked on by natural scientists convert the knowledge originating from the humanities back into knowledge typical for the natural sciences and thus impoverish such research. Furthermore, any collaboration at the juncture of diverse disciplines engenders transdisciplinary solutions (Zeidler 2010), which I would call cultural-scientific if cultural studies are assumed to mean an integrated discipline (Pałubicka 2010). Hence, cultural studies, as the leading discipline, is called upon to engage in studies of cultural landscape presented in the above project.

The methodological problem which should be resolved in the first place consists in the fact that science still employs analytical methods and corresponding analytical concepts and discourse not compliant with the synthetic perception processes. One should therefore devise synthetic methods and notions which are sufficiently precise as opposed to being "containers" into which one deposits a chaotic set of data. This is an exceedingly difficult undertaking, in which we might be aided by green architects, environmental protection architects, and ecologists with mathematical expertise, in order to apply tools such as curves based on fuzzy sets or multi-valued logics.

I sincerely hope that the achievement of the humanities and social researchers, hitherto poorly applied in practice, will be taken advantage of by the designers of green areas, conservation officers and ecologists, or the staff of landscape parks. On the other hand, we will obtain empirical data which could transform the knowledge of social sciences into subdisciplines or applied fields. For the present, 
both milieus remain divided (the beginnings of the dispute date back to the $19^{\text {th }}$ century), which leads to simplified, dehumanized or unimaginative designs of urban greenery or recreational sites. For their part, researchers in the domains of humanities and social sciences turn out studies which are detached from cultural and social practice.

Academic-level landscape education, introduced in the curricula at various faculties and departments, could play a fundamental and momentous role in accomplishing these objectives. Here I refer not only to natural sciences, including technical majors and specialties, but also education studies-whose graduates would then implement the acquired knowledge at lower levels of social education, preparing their pupils to take up culture-related studies, as well as implementing the knowledge they have gained by making it an applied discipline which transcends the walls of universities.

\section{Bibliography:}

Angutek, Dorota. 2010. "Kanadyjska antropologia zmysłów —alternatywa wobec postmodernizmu."

["Canadian Anthropology of the Senses — an Alternative to Postmodernism] Lud 94: 221-242.

Angutek, Dorota. 2013. "Epistemologiczne problemy badań interdyscyplinarnych" ["Epistemological

Problems of Interdisciplinary Research"]. Studia Europaea Gnesnensia 8: 131-158.

Angutek, Dorota. 2013a. Kulturowe wymiary krajobrazu. Antropologiczne studium recepcji krajobrazu

na prowincji: od teorii do empirii [Cultural Dimensions of Landscape. An anthropological study

on landscape in the provinces: from theory to empirical data]. Poznań: Bogucki Wydawnictwo Naukowe.

Arendt, Hannah. 1998. Kondycja ludzka, trans. by Anna Łagodzka. Warszawa: Aletheia [English original:

Arendt, Hannah. 1998. The Human Condition. Chicago: University of Chicago Press]

Bateson, Gregory. 1972. "Effects of Conscious Purpose on Human Adaptation." In Gregory Bateson,

Steps to Ecology of Mind Collected Essays in Anthropology, Psychiatry, Evolution and Epistemology,

313-318. Northvale-London: Jason Aronson Inc.

Burszta, Wojciech J. 1987. "Kultura jawna/kultura ukryta" ["Explicit Culture/Implicit Culture".] In Stownik etnologiczny. Terminy ogólne, ed. by Zofia Staszczak, 194-195. Warszawa-Poznań: PWN.

Carr, Nicholas. 2010. Plytki umyst. Jak Internet wplywa na nasz mózg, transl. by Katarzyna Rojek. Gliwice: Hellion S.A. [English original: Carr, Nicholas. 2010. The Shallows: How the Internet is Changing the Way we Think, Read and Remember. London: Atlantic Books]

Damasio, Antonio R. 1999. The Feeling of What Happens. New York: Harcourt Brace \& Company.

Damasio, Antonio R. 2010. Self Comes to Mind: Constructing the Conscious Brain. New York: Pantheon.

Gibson, James J. 1979. The Ecological Approach to Visual Perception. Boston: Houghton Mifflin.

Janion, Maria. 1994. Kuźnia Natury [The Forge of Nature]. Gdańsk: Słowo/Obraz Terytoria.

Kmita, Jerzy. 1985. Kultura i poznanie [Culture and Knowledge]. Warszawa: PWN.

LeDoux, Joseph. 1996. The Emotional Brain. New York: Simon \&Schuster. 
Macnaghten, Phil, Urry, John. 1998. Contested Natures. Thousand Oaks and New Delhi: Sage Publications of London.

Pałubicka, Anna. 2010. "Kulturoznawstwo jako dyscyplina zintegrowana" ["Cultural Studies as an Integrated Discipline"]. In Kulturo-znawstawo. Dyscyplina bez dyscypliny?, ed. by Wojciech J. Burszta and Michał Januszkiewicz, 35-50. Warszawa: Wydawnictwo SWPS Academica.

Pałubicka, Anna. 2013. Gramatyka kultury europejskiej [Grammar of European Culture]. Bydgoszcz: Oficyna Wydawnicza Epigram

Przegalińska, Aleksandra K. 2013. Fenomenologia istot wirtualnych [Phenomenology of Virtual Entities] Doctoral dissertation. Accessed on July 2, 2015.

Turner, Victor W., Bruner, Edward M., eds. 1986. The Anthropology of Experience Illinois: Board of Trustees of the University of Illinois.

Varela, Francisco J., Rosch, Eleanor, and Thompson, Evan. 1991. The Embodied Mind: Cognitive Science and Human Experience. Cambridge: The MIT Press.

Zeidler-Janiszewska, Anna. 2010. "Granice współczesności granicami 'znawstwa'? Kilka uwag o miejscach skrzyżowania badań kulturoznawczych z badaniami historyków" ["The Limits of the Contemporary as the Limits of 'Expertise'? A Few Remarks at the Intersection of Cultural studies and Historical Research"]. In: Kulturo-znawstwo. Dyscyplina bez dyscypliny?, ed. by Wojciech J. Burszta and Michał Januszkiewicz, 22-34, Warszawa: Wydawnictwo SWPS Academica.

Znaniecki, Florian. 1988. Wstęp do socjologii [Introduction to Sociology]. Warszawa: PWN. 